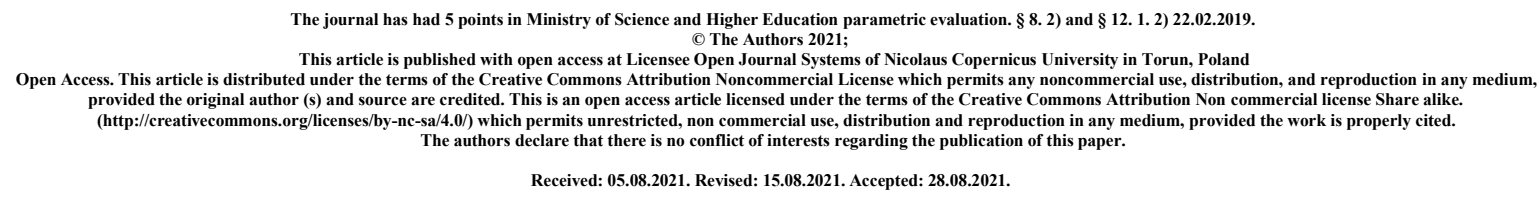

\title{
Proton pump inhibitors usage and the risk of cancer
}

\author{
Hubert Wróblewski, Aleksandra Zimna
}

\section{Faculty of Medicine, Medical University of Lublin}

\begin{abstract}
Introduction and purpose of the work:Proton pump inhibitors are used to reduce gastric acidity by irreversibly inhibiting the hydrogen-potassium ATPase present in the parietal cells of the stomach. These drugs are used more and more often, often not in accordance with the recommendations. There are reports suggesting a relationship between chronic PPI use and the occurrence of cancer. The aim of the study is to present information on the relationship between the use of proton pump inhibitors and the risk of developing cancer.

State of knowledge:Recent field studies have shown that there is a significant relationship between PPI use and carcinogenesis. One possible mechanism is related to the sustained release of gastrin in large amounts, which in turn stimulates the production of substances with trophic effects on the gastrointestinal mucosa, and cell proliferation over time may lead to cancer formation. The relationship between high gastrin concentration and the formation of gastric neuroendocrine neoplasms, tumors of the liver, pancreas and esophagus has been proven.

Summary:Proton pump inhibitors are considered safe drugs. Taking into account the described reports on the increased risk of developing certain cancers, when prescribing PPIs, the risk associated with their use should also be taken into account. However, it seems that the benefits of using these drugs outweigh the risks in most cases.
\end{abstract}

Key words: proton pump inhibitors; tumor; risk factor 
Wprowadzenie i cel pracy: Inhibitory pompy protonowej są stosowane w celu zmniejszenia kwaśności soku żołądkowego poprzez nieodwracalne hamowanie ATP-azy wodorowopotasowej obecnej w komórkach okładzinowych żołądka. Leki te są stosowane coraz częściej, nierzadko niezgodnie z zaleceniami. Pojawiają się doniesienia sugerujące związek między przewlekłym stosowaniem IPP a występowaniem nowotworów. Celem pracy jest przedstawienie informacji na temat związku między stosowaniem inhibitorów pompy protonowej a ryzykiem zachorowania na nowotwór.

Stan wiedzy: Ostatnio przeprowadzone badania populacyjne dowiodły, iż istnieje istotny związek między przyjmowaniem IPP i kancerogenezą. Jeden z możliwych mechanizmów wiąże się z przedłużonym uwalnianiem gastryny w dużych ilościach, która z kolei pobudza powstawanie substancji, wykazujących troficzne działanie na błonę śluzową przewodu pokarmowego, a rozrost komórek $\mathrm{z}$ czasem może prowadzić do nowotworzenia. Udowodniono związek między wysokim stężeniem gastryny, a powstawaniem nowotworów neuroendokrynnych żołądka, nowotworów wątroby, trzustki, przełyku.

Podsumowanie: Inhibitory pompy protonowej są uznawane za leki bezpieczne. Biorąc pod uwagę opisane doniesienia dotyczące zwiększonego ryzyka zachorowania na niektóre nowotwory zalecając IPP należy wziąć pod uwagę również ryzyko, jakie ich stosowanie ze sobą niesie. Wydaje się jednak, iż korzyści wynikające ze stosowania tych leków w większości przypadków przewyższa ryzyko.

Slowa kluczowe: inhibitory pompy protonowej; guz; czynnik ryzyka

\section{Wprowadzenie i cel pracy}

Inhibitory pompy protonowej to leki dostępne na rynku farmaceutycznym od kilkudziesięciu lat. Są stosowane w celu zmniejszenia kwaśności soku żołądkowego poprzez nieodwracalne hamowanie ATP-azy wodorowo-potasowej obecnej w komórkach okładzinowych żołądka. Od kilku lat stosowanie tych leków stale się zwiększa.(1). Wskazaniami do stosowania inhibitorów pompy protonowej są choroba wrzodowa żołądka $\mathrm{i}$ dwunastnicy, eradykacja Helicobacter pylori, dyspepsja rzekomowrzodowa, profilaktyka zachłystowego zapalenia płuc u leżących chorych, choroba refluksowa przełyku, zespół Zollingera-Ellisona, leczenie i profilaktyka uszkodzeń błony śluzowej górnego odcinka przewodu pokarmowego w następstwie przewlekłego stosowania niesteroidowych leków przeciwzapalnych.(2) Obok powszechnie znanych i dobrze udokumentowanych wskazań, IPP( Inhibitory pompy protonowej) są coraz szerzej zalecane w chorobach i sytuacjach klinicznych, w których nie udowodniono jednoznacznie korzyści z leczenia przeciwsekrecyjnego. Co więcej, leki te często bywają również nadużywane oraz stosowane niezgodnie z wytycznymi, czemu z pewnością sprzyja dostępność niektórych z nich bez recepty.(3) 
W charakterystyce produktu leczniczego leków z opisywanej grupy wymienia się liczne działania niepożądane, takie jak bóle głowy, biegunka, zaparcia, wzdęcia i bóle brzucha oraz ostrzeżenia związane $\mathrm{z}$ możliwością wystąpienia zaburzeń wchłaniania witaminy B12, zakażeń bakteryjnych przewodu pokarmowego czy hipomagnezemii i osteoporozy (4), jednak pojawiają się również doniesienia sugerujące związek między przewlekłym stosowaniem IPP a występowaniem nowotworów.

\section{Stan wiedzy}

Inhibitory pompy protonowej

Wszystkie obecnie zatwierdzone PPI są pochodnymi benzoimidazolu. Po opuszczeniu żołądka PPI są wchłaniane w proksymalnym jelicie cienkim. Inhibitory pompy protonowej są prolekami (substancjami nieczynnymi farmakologicznie), ulegającymi aktywacji w środowisku kwaśnym. Po wchłonięciu inhibitory pompy protonowej są transportowane do aktywowanych komórek okładzinowych żołądka, gdzie koncentrują się w kwaśnych kanalikach wydzielniczych, gdzie ulega aktywacji.(5). Aktywna cząsteczka leku, łącząc się trwale $\mathrm{z}$ jednym $\mathrm{z}$ aminokwasów (cysteiną) enzymu jakim jest pompa protonowa, nieodwracalnie ją unieczynnia. Zmniejszone wydzielanie się kwasu solnego umożliwia zagojenie zmian związanych $\mathrm{z}$ uszkodzeniem błony śluzowej żołądka, dwunastnicy lub przełyku oraz stwarza odpowiednie warunki do działania antybiotyków w przypadku eradykacji Helicobacter pylori.(6) PPI nieodwracalnie blokują ATPazę wodorowo-potasową, czyniąc ten enzym nieaktywnym. W ten sposób wszelkie formy stymulacji wydzielania jonów wodorowych ulegają zahamowaniu, aż do chwili zsyntetyzowania białek nowej pompy protonowej. Czas połowiczej aktywności tej pompy wynosi ok. 18 godz., aktywność wydzielnicza komórek okładzinowych po jej inaktywacji powraca do normy po 2-5 dniach od zaprzestania stosowania leku.(2)

Co ciekawe, niektóre $\mathrm{z}$ nich są również dostępne w postaci dożylnej. Wykazano, iż są one skuteczne w zapobieganiu nawrotu krwawienia i poprawie wyników leczenia po endoskopowym zatrzymaniu krwawienia $\mathrm{z}$ wrzodu trawiennego. W jednym $\mathrm{z}$ badań $\mathrm{u}$ chorych z PPI podawanymi dożylnie wykazano dłuższy czas utrzymywania się pH wewnątrzżołądkowego powyżej 6 niż u osób otrzymujących PPI doustnie (67,8\% vs. 64,8\%; $95 \%$ CI: $-9,2 \%-15,2 \%)$. (2)

Wykazano, że w celu wyleczenia choroby wrzodowej dwunastnicy optymalne docelowe pH powinno przez 18-20 godzin na dobę wynosić więcej niż 3, natomiast w przypadku choroby wrzodowej żołądka więcej niż 4. IPP są jedyną grupą leków, pozwalającą na tak długą kontrolę $\mathrm{pH}$. Posiadają zdolność do utrzymania $\mathrm{pH}>4$ przez nawet 15-21 godzin, umożliwiają również kontrolę pH w nocy. Inne leki oddziałują na receptory, co powoduje szybkie powstawanie tolerancji - prawdopodobnie na skutek wyrównawczego zwiększenia aktywacji pozostałych receptorów.(7) 
Stosowanie inhibitorów pompy protonowej a ryzyko wystąpienia nowotworu

Ostatnio przeprowadzone badania populacyjne dowiodły, iż istnieje istotny związek między przyjmowaniem IPP i kancerogenezą. Pod uwagę bierze się dwa mechanizmy: pierwszy wiąże się z przedłużonym uwalnianiem gastryny $\mathrm{w}$ dużych ilościach, która $\mathrm{z}$ kolei pobudza powstawanie substancji, wykazujących troficzne działanie na błonę śluzową przewodu pokarmowego, a rozrost komórek z czasem może prowadzić do nowotworzenia. Udowodniono związek między wysokim stężeniem gastryny, a powstawaniem nowotworów neuroendokrynnych żołądka, nowotworów wątroby, trzustki, przełyku. Drugi mechanizm wiąże się z upośledzeniem metabolizmu kwasów żółciowych, które indukują powstawanie reaktywnych form tlenu i azotu, co prowadzi do uszkodzeń DNA i mutacji nowotworowych.(7)

Jedno $\mathrm{z}$ badań dotyczących związku między stosowaniem IPP a rakiem trzustki obejmowało 4113 pacjentów $\mathrm{z}$ tym nowotworem. Rozpowszechnienie stosowania IPP(aktywnego lub byłego) było większe u osób z rozpoznaniem raka trzustki, przy czym $52,9 \%$ (2175 z 4113 pacjentów) było aktywnymi użytkownikami w porównaniu do 26,2\% (4217 z 16072 pacjentów) w grupie kontrolnej i 43,8\% (1801 z 4113 pacjentów) przypadków, które nigdy nie były użytkownikami, w porównaniu z 72,0\% (11576 z 16072 pacjentów) w grupie kontrolnej. Pacjenci obecnie stosujący IPP krótkoterminowo mieli największy OR $(10,60,95 \%$ CI 9,36-11,79), podczas gdy osoby stosujące te leki w przeszłości (OR 3,54, 95\% CI 2,83, 4,43), średnioterminowi (OR 2,54, 95\% CI 2,16, 3,00), i długotrwale obecnie stosujący (OR 1,94, 95\% CI 1,74, 2,14) wszyscy mieli niższe, lecz znacznie podwyższone ryzyko w porównaniu $\mathrm{z}$ osobami niestosującymi IPP.(8) Podobne wyniki odnotowano w koreańskich badaniach. Stwierdzono, iż osoby o zwiększonej ekspozycji na IPP mają zwiększone ryzyka raka trzustki w porównaniu z osobami, które ich nie stosowały (HR 1,32; 95\% CI 1,03-1,70). Ekspozycja na IPP wydawała się wpływać na ryzyko wystąpienia raka endokrynnego trzustki, ale nie osiągnęła istotności statystycznej. Znaczący wpływ zwiększonej ekspozycji na IPP na rozwój raka trzustki pozostał silny w grupach niskiego ryzyka, w tym kobiet i osób, które prowadziły zdrowy tryb życia.(9) Z kolei w szwedzkich badaniach raka trzustki wykryto u 1733 długotrwale stosujących IPP i 25 stosujących antagonistę receptora $\mathrm{H} 2$. W przypadku osób stosujących IPP, ryzyko raka trzustki było ogólnie zwiększone (SIR = 2,22; 95\% CI 2,12-2,32) i we wszystkich analizach podgrup, przy czym najwyższe ryzyko było wśród użytkowników IPP w wieku poniżej 40 lat (SIR = 8,90, 95\% CI 4,26-16,37) oraz wśród osób z Helicobacter pylori $w$ wywiadzie (SIR = 2,99, 95\% CI 2,54-3,49). Ryzyko było związane z czasem stosowania. Nie odnotowano, aby stosowanie antagonistów receptora $\mathrm{H} 2$ było związane ze zwiększonym ryzykiem raka trzustki.(10)

Cheung $i$ wsp. wykazali dodatnią korelację między IPP a rakiem żołądka u pacjentów zakażonych H. pylori, którzy przeszli terapię eradykacyjną. Stosowanie IPP istotnie zwiększało ryzyko raka żołądka [współczynnik ryzyka $(\mathrm{HR})=2,44 ; 95 \% \mathrm{CI}$ : 1,42-4,20]. Co więcej, dodatni związek między PPI a rakiem żołądka wykazał zależność zależną od dawki i czasu trwania. Wykazano zwiększone ryzyko raka żołądka przy długotrwałym stosowaniu IPP, nawet po skutecznej eradykacji H. pylori.(11) Szwedzkie, populacyjne badanie kohortowe obejmowało prawie 800000 szwedzkich dorosłych, którzy przechodzili leczenie podtrzymujące PPI, a wskaźnik istotności (SIR) raka żołądka wyniósł 3,38 (95\% CI: 3,23- 
3,53). Jednak w tym badaniu nie udało się ustalić związku przyczynowego między rakiem żołądka a długotrwałym stosowaniem IPP, ponieważ SIR raka żołądka nie wykazywał żadnego wzoru zależnego od czasu trwania. Ponadto brakowało kluczowych informacji, takich jak aktualny stan infekcji H. pylori. Brakuje wyników klinicznych potwierdzających wpływ długotrwałego stosowania IPP na rozwój stanów przedrakowych, takich jak zanikowe zapalenie żołądka czy metaplazja jelitowa.(12)

Ostatnio donoszono również, że IPP są związane z zapaleniem pęcherzyka żółciowego i mogą być rakotwórcze. Przeprowadzono szpitalne badanie kliniczno-kontrolne obejmujące 3030 pacjentów (606 pacjentów z patologicznie zdiagnozowanym rakiem pęcherzyka żółciowego oraz 2424 osoby zdrowe). Stwierdzono, iż stosowanie IPP wiązało się z 1,56krotnie zwiększonym ryzykiem raka pęcherzyka żółciowego $(\mathrm{p}<0,0001)(\mathrm{OR}=1,56,95 \% \mathrm{CI}$ $1,07$ do 2,19; $\mathrm{p}=0,005)$. Zwiększone ryzyko zachorowania na opisany wyżej nowotwór można tłumaczyć zmianami spowodowanymi hipochlorhydrią wywołaną stosowaniem IPP flory żołądka i pH jelita cienkiego, umożliwiając rozwój bakterii, tym samym zwiększając ryzyko retrogradacji dróg żółciowych, a tym samym podnosząc częstość występowania infekcji dróg żółciowych, które są czynnikami ryzyka zachorowania na raka pęcherzyka żółciowego.(13)

W kwestii wpływu stosowania IPP i związanego z nim ryzyka zachorowania na raka jelita grubego nie można jednoznacznie uznać stosowania tych leków za czynnik ryzyka rozwoju wspomnianego wyżej nowotworu. Długotrwałe stosowanie IPP zmienia florę jelitową poprzez hipochlorhydrię i alkalizację, prowadząc do infekcji jelitowych. Stwierdzono, że dhugotrwałe stosowanie IPP powoduje infekcję jelitową Clostridium perfringens. enterotoksyna $C$. perfringens (CPE) zwiększa złośliwość nowotworu.(14) Pomimo potencjalnego biologicznego powiązania między lekami hamującymi wydzielanie kwasu a rakiem jelita grubego, związek ten nie został wystarczająco zbadany $w$ badaniach epidemiologicznych. W prowadzonych kohortowych badaniach w Stanach Zjednoczonych wynika, iż stosowanie IPP nie wiąże się z wyższym ryzykiem raka jelita grubego; (współczynnik ryzyka $(\mathrm{HR})=0,89,95 \%$ przedział ufności $(\mathrm{CI}), 0,71-1,12$ ) lub stosowaniem PPI po 8-10 latach opóźnienia $(\mathrm{HR}=1,12,95 \% \mathrm{CI}, 0,78-1,59)$ z ryzykiem raka jelita grubego. Co ciekawe, obecne stosowanie IPP wiązało się ze zmniejszonym ryzykiem zachorowania na ten nowotwór ( $\mathrm{HR}=0,82,95 \% \mathrm{CI}, 0,68-0,98) .(15)$

\section{Podsumowanie}

Inhibitory pompy protonowej są uznawane za leki bezpieczne, co prowadzi do ich nadużywania i długotrwałego stosowania mimo braku jednoznacznych wskazań.(1) Ponadto są one uznawane za najskuteczniejsze leki obniżające pH żołądka. Biorąc pod uwagę opisane doniesienia dotyczące zwiększonego ryzyka zachorowania na niektóre nowotwory zalecając IPP należy wziąć pod uwagę również ryzyko, jakie ich stosowanie ze sobą niesie. Wydaje się jednak, iż korzyści wynikające ze stosowania tych leków w większości przypadków przewyższa ryzyko. 


\section{References}

1. Kozłowski J, Kardymowicz A, Manitius J. Bezpieczeństwo stosowania inhibitorów pompy protonowej u chorych z przewlekłą chorobą nerek - aktualny stan wiedzy. Varia Medica [Internet]. 2018;2(4):319-25.

2. Skuteczność esomeprazolu podawanego dożylnie i doustnie w prewencji nawrotu krwawienia z wrzodu po leczeniu endoskopowym | Gastroenterologia Praktyczna czasopismo lekarza praktyka [Internet].. Available from: https:/gastroenterologiapraktyczna.pl/a2053/Skutecznosc-esomeprazolu-podawanego-dozylnie-i-doustnie-wprewencji-nawrotu-krwawienia-z-wrzodu-po-leczeniu-endoskopowym.html/m336

3. Inhibitory pompy protonowej - bilans korzyści i ryzyka - Artykuły przeglądowe Artykuły i wytyczne - Pediatria - Medycyna Praktyczna dla lekarzy [Internet]. Available from: https://lekarz.mp.pl/pediatria/artykuly-wytyczne/artykulyprzegladowe/82125, inhibitory-pompy-protonowej-bilans-korzysci-i-ryzyka

4. Charakterystyka produktu

leczniczego. http://leki.urpl.gov.pl/files/30_PantoprazoleMercapharm_40.pdf

5. Strand DS, Kim D, Peura DA. 25 Years of Proton Pump Inhibitors: A Comprehensive Review. Gut Liver . 2017 Jan 1;11(1):27.

6. Pantoprazol - Medycyna Praktyczna [Internet]. Available from: https://www.mp.pl/pacjent/leki/subst.html?id=641

7. Uździcki A, Awgul S, Słuczanowska-głąbowska S. Wybrane doniesienia na temat zagrożeń i powikłań związanych z terapią przy użyciu inhibitorów pompy protonowej Chosen reports on the risks and complications associated with proton pump inhibitor therapy. Farmacja współczesna 2017; 10: 168-176.

8. Kearns MD, Boursi B, Yang Y-X. Proton pump inhibitors on pancreatic cancer risk and survival. Cancer Epidemiol. 2017 Feb $1 ; 46: 80$.

9. Hwang IC, Chang J, Park SM. Association between proton pump inhibitor use and the risk of pancreatic cancer: A Korean nationwide cohort study. PLoS One. 2018 Sep 1;13(9). Available from: /pmc/articles/PMC6135510/

10. Brusselaers N, Sadr-Azodi O, Engstrand L. Long-term proton pump inhibitor usage and the association with pancreatic cancer in Sweden. J Gastroenterol. 2020 Apr $1 ; 55(4): 453$.

11. Cheung KS, Leung WK. Long-term use of proton-pump inhibitors and risk of gastric cancer: a review of the current evidence. Therap Adv Gastroenterol. 2019 Mar 1 [;12.

12. Joo MK, Park J-J, Chun HJ. Proton pump inhibitor: The dual role in gastric cancer. World J Gastroenterol. 2019;25(17):2058.

13. Xiong J, Wang Y, Chen G, Jin L. Proton pump inhibitors and the risk of gallbladder cancer: a hospital-based case-control study. Gut. 2020 Dec 1;69(12):2265.

14. Sasaki T, Mori S, Kishi S, Fujiwara-Tani R, Ohmori H, Nishiguchi Y, et al. Effect of Proton Pump Inhibitors on Colorectal Cancer. Int J Mol Sci. 2020 Jun 1;21(11):1-12. 
15. Babic A, Zhang X, Morales-Oyarvide V, Yuan C, Khalaf N, Khalili H, et al. Acidsuppressive medications and risk of colorectal cancer: results from three large prospective cohort studies. Br J Cancer. 2020 Sep 1;123(5):844. 